\title{
Psychological preparedness of coastal communities in Surabaya: a preliminary finding
}

\author{
Listyati Setyo Palupi ${ }^{* 2345}$ \\ ${ }^{1}$ Psychology Department, Universitas Airlangga, Jl. Airlangga 4-6, Surabaya, East Java, Indonesia \\ ${ }^{2}$ Addiction Study Centre, Jl. Airlangga 4-6, Surabaya, East Java, Indonesia \\ ${ }^{3}$ Health and Environmental Sustainability Research Group, Jl. Airlangga 4-6, Surabaya, East Java, Indonesia \\ ${ }^{4}$ Technology and Psychology of Social Change Research Group, Jl. Airlangga 4-6, Surabaya, East Java, Indonesia \\ ${ }^{5}$ Direktorat Riset dan Pengabdian Masyarakat (DRPM) RISTEKDIKTI Indonesia Penelitian Dasar (PD) research funding scheme \\ 2021 (No. 528/UN3.15/PT/2021)
}

\begin{abstract}
Indonesia has been acknowledged as one of countries that has the largest coastline in the world after Canada and Norway. Situated between Australia plate, Pacific plate, and Eurasia plate has made the country prone to disaster. Tsunami is one of the disasters that struck coastal communities in Indonesia. Tsunami is one type of disaster that bring devastated impact economically, socially and psychologically especially for the coastal communities including for Surabaya community that live along the coast. Studies found that psychologically preparing individual to face disaster could help to reduce the psychological impact of the disaster. Therefore, identifying the psychological preparedness is pertinent to reduce the risk of disaster especially for the coastal communities in Surabaya that were prone to tsunamis and other natural hazards. The purpose of the study is to describe the psychological preparedness for disaster of coastal communities in Surabaya. The result shows that the psychological preparedness for disaster of the participants was mostly in average level. Therefore, psychological preparedness for disaster needs to be improved especially among female with age between 12-35 years old population in order to reduce the risk of psychological impact of disaster.
\end{abstract}

\section{Introduction}

Indonesia is surrounded by Australia plate, Pacific plate, and Eurasia plate. This situation has made Indonesia prone to disaster. As an archipelagic country, Indonesia is known as country that has the largest coastline in the world after Canada and Norway. Therefore, Indonesia is included as an archipelagic country that are prone to disaster.

According The National Disaster Management Agency of Indonesia record, there are 28.100 disaster that happen in Indonesia in 10-year period from 2011 until 2021 [1]. Record of disaster composition that happen in Indonesia from January until August 2021 could be seen in figure 1 below.

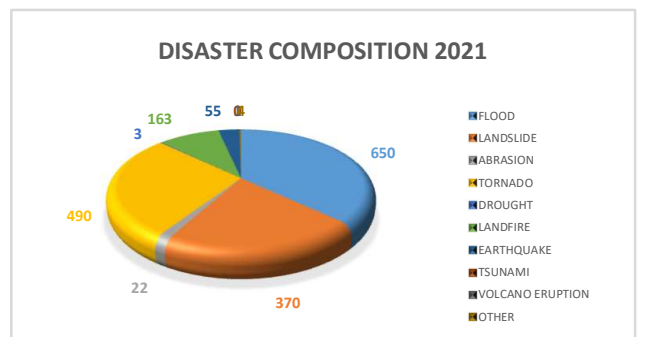

Fig. 1. Type of disaster happen in Indonesia in 2021 [1].

\footnotetext{
* Corresponding author: listyati.palupi@psikologi.unair.ac.id
}

Disaster that happens from January to August 2021 has happen in almost every province in Indonesia from Aceh to Papua. Several provinces in Indonesia that struck by disaster in 2021 has been record by Indonesian Disaster Data and Information Database (DIBI) below.

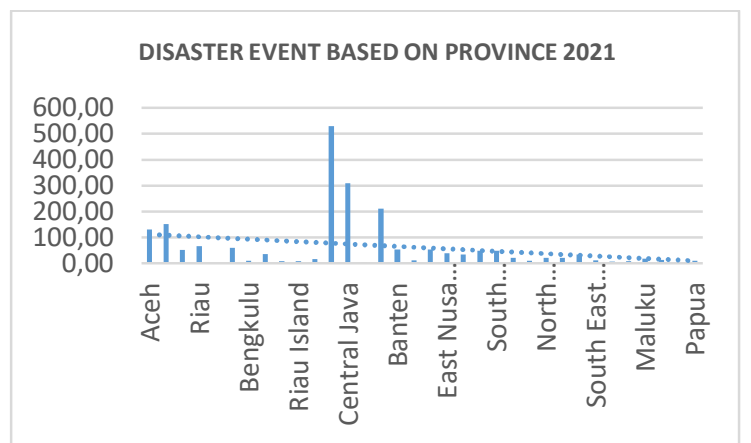

Fig. 2. Disaster occurrence based on province 2021 [1].

East Java Province is on the third position among 34 provinces in Indonesia that experience disaster in 2021. Disaster that often happen in East Java in 2021 are flood, cyclone, landslide, and eruption [2]. There are several cities in East Java that are identified as disaster-prone area including Surabaya.

Surabaya is one of region in Indonesia that reside along the coastline. Geographical location of Surabaya 
made the region prone to hydrological hazard such as flood, drought, and tsunami.

Disaster could incur devastated impact economically, socially and psychologically to the society. Infrastructure damage, settlement damage and also industrial damage has affected the economic condition of the community affected by the disaster. Beside of that, being separated from other family member, have to live in a shelter, and loss of privacy is among other social impact of disaster [3]. Disaster victim could also experience mental health issue as a result of being exposed to a disaster event. Research that focuses on psychological impact of disasters has found that disasters experience has induces several psychological problems to the survivor. The survivor could develop acute stress disorder, post-traumatic stress disorder (PTSD) and also other psychological disorders [4-8].

There have been several interventions that are develop to reduce the psychological impact of disaster. However, the interventions were only focus in technical preparedness and neglecting the psychological aspects of disaster preparedness. Studies found that psychologically preparing individual to face disaster could help to reduce the psychological impact of the disaster [9-11].

Several authors have defined psychological preparedness. According to Roudini et al (2017), psychological preparedness is "... a state of awareness and expectation of an individual's psychological reactions to the disaster warning ... mental health preparedness will significantly support the ability to identify particular stress-related emotions and thoughts ... this also contains the perception, appraisal, and understanding of threatening events and the risk communication" [12]. Another definitifon of psychological preparedness is propose by Zulch (2015) which is "a heightened state of awareness, anticipation, and readiness for: (1) the uncertainty and emotional arousal in expectation of the possible occurrence of the threat, (2) one's own psychological response to the unfolding threat situation, and (3) the ability to manage the demands of the situation" [13]. Boyland () extend the definition provide by Zulch and define psychological preparedness as multidimensional construct ... the multiple attributes are: 1) perceived control over one's coping ability; 2) perceived control over the environmental outcomes; 3) a general understanding of the risk context; and 4) proactive planning and preparing for the threat" [14]. Various definition has been proposed nonetheless psychological preparedness for disaster is still understudied. Study found that the available research that investigate psychological preparedness for disaster are limited [15].

Research found that, psychologically preparing individual to successfully manage a disaster situation or disaster could also influence their resilience [16]. Thus, psychological preparedness for disaster is an important aspect to reduce the risk of disaster especially for coastal communities such as in Surabaya that were prone to tsunamis and other natural hazards. The purpose of this study is to describe the psychological preparedness for disaster of coastal communities in Surabaya.

\section{Method}

This study was conducted using online survey research with 583 people participants involved in this research. The invitation to the general population to be involve in this study was send in social media such as Facebook, Instagram and online communication platform such as WhatsApp.

All respondents should complete Psychological Preparedness for Disaster scale that are developed by the author.

\subsection{Measurements}

The Psychological Preparedness for Disaster (PPD) scale consists of three parts which are informed consent, identity, and the question or statement. The participants

First part of this scale was provided to record the participant's informed consent. The second part is a part where participants fill their identity which includes: age, gender, and socioeconomic status. The third part is the Psychological Preparedness for Disaster scale 1.1. This scale consists of 34 items version which include 17 items of affective dimension, 8 item of behaviour dimension, and 9 item of cognitive dimension. The internal consistency of the scale is a $=0.84$. Data were analysed by using descriptive statistical method.

The total score of PPD scale is acquire by summing up the score on each item. The total Scores can range from 34 to 68. The mean of the PPD score is Higher score indicates higher psychological preparedness for disaster.

The participants total score then classified into three group which is low, average, and high. The classification was made based on the equal interval classification [17]. Participant with score below 46 is considered low, score between 46 up to 57 is average, and score above 57 is high.

\section{Results}

Based on age, data shows that the majority of the participant or $99 \%$ participant in young adulthood ((1524 years old) category. The majority of the participant that have average level of psychological preparedness for disaster in this study is $67 \%$. High and low level of psychological preparedness are found in $23 \%$ and $10 \%$ respectively.

Participant socioeconomic status is mostly at lowincome category with $63 \%$. While, middle-, and highincome group were $22 \%$, and $15 \%$ respectively.

\subsection{Demographic profile}

The participants involve in this study were 583 people Surabaya resident. The gender composition in this study are $73 \%$ female and $27 \%$ male. The participants age group range between 15 years old until 33 years old.

The participants were mostly from low-income socio-economic status (57\%). While the middle-income group and high-income group were only $22 \%$ and $15 \%$ respectively. 
There are only three age categories that count in his study which are youth (11-14yo), young adulthood (1524 years old) and middle adulthood (25-44 years old) with $0.2 \%, 99 \%$ and $0.8 \%$ respectively. Participants demographic profile are depict in table 1 below.

Table 1. Demographic profile.

\begin{tabular}{|c|c|c|}
\hline Characteristic & $\mathrm{f}$ & $\%$ \\
\hline \multicolumn{3}{|l|}{ Age group (years) } \\
\hline Youth (1-14yo) & 1 & 0.2 \\
\hline Young adulthood (15-24yo) & 585 & 99 \\
\hline Middle adulthood (25-44yo) & 5 & 0.8 \\
\hline \multicolumn{3}{|l|}{ Gender } \\
\hline Female & 431 & 73 \\
\hline Male & 160 & 27 \\
\hline \multicolumn{3}{|l|}{ Socioeconomic status } \\
\hline Low income & 375 & 63 \\
\hline Middle income & 128 & 22 \\
\hline High Income & 88 & 15 \\
\hline
\end{tabular}

\subsection{Psychological preparedness level}

Most of the population in this study has average level of psychological preparedness for disaster (66\%). People with average level of psychological preparedness were dominated by female with $50 \%$ of total population. They mostly come from low-income group with $43 \%$ out of the total respondents in this study. The participant level of psychological preparedness for disaster summarized in Table 2.

Table 2. Psychological preparedness level

\begin{tabular}{|c|c|c|}
\hline Psychological preparedness level & $\mathrm{f}$ & $\%$ \\
\hline Low & 58 & 10 \\
\hline Average & 395 & 67 \\
\hline High & 138 & 23 \\
\hline
\end{tabular}

\subsection{Psychological preparedness level based on socioeconomic status}

The participants of this study were come from low-, middle-, and high-income socioeconomic status. The participants from low-income level were 375 participants or $63 \%$. While, people from middle and high-income group are $22 \%$ and $15 \%$ respectively.

The majority of the respondent from low-income group were have average level of psychological preparedness for disaster with $43 \%$. The number of participants in the low-income status that have low and high level of psychological preparedness were only $5 \%$ and $15 \%$ respectively.

Respondents in middle income group mostly have average level of psychological preparedness with $14 \%$ of the total population. Whereas the second biggest number of middle-income participants were in the high level of psychological preparedness with $3 \%$ from the total population. The last was participants with low level of psychological preparedness for disaster with only $3 \%$.

The greatest number of people with high income status have average level of psychological preparedness for disaster. The high-income status with low and high psychological preparedness were both only $2 \%$ from the total population.

The summary of psychological preparedness for disaster level based on socioeconomic status could be found in table 3 .

Table 3. Psychological preparedness level based on socioeconomic status.

\begin{tabular}{|c|l|l|l|}
\hline $\begin{array}{c}\text { Psychological } \\
\text { Preparedness level }\end{array}$ & \multicolumn{1}{|c|}{ Socioeconomic } & f & \multicolumn{1}{c|}{$\%$} \\
\hline \multirow{4}{*}{ Low } & Low income & 32 & 5 \\
\cline { 2 - 4 } & Middle income & 15 & 3 \\
\cline { 2 - 4 } & High income & 11 & 2 \\
\hline \multirow{3}{*}{ Average } & Low income & 252 & 43 \\
\cline { 2 - 4 } & Middle income & 80 & 14 \\
\cline { 2 - 5 } & High income & 63 & 10 \\
\hline \multirow{3}{*}{ High } & Low income & 91 & 15 \\
\cline { 2 - 5 } & Middle income & 33 & 6 \\
\cline { 2 - 5 } & High income & 14 & 2 \\
\hline
\end{tabular}

\subsection{Psychological preparedness level based on age}

The vast majority of the population were in young adulthood category follow by youth, young adulthood, and middle adulthood category with $0.2 \%, 99 \%$ and $0.8 \%$ respectively.

Table 4. Psychological preparedness level based on age

\begin{tabular}{|c|c|c|c|}
\hline $\begin{array}{l}\text { Psychological Preparedness } \\
\text { level }\end{array}$ & Age & $\mathrm{f}$ & $\%$ \\
\hline \multirow[t]{3}{*}{ Low } & Youth & 1 & 0.2 \\
\hline & Young adulthood & 57 & 10 \\
\hline & $\begin{array}{l}\text { Middle } \\
\text { adulthood }\end{array}$ & 0 & 0 \\
\hline \multirow[t]{3}{*}{ Average } & Youth & 0 & 0 \\
\hline & Young adulthood & 391 & 66 \\
\hline & $\begin{array}{l}\text { Middle } \\
\text { adulthood }\end{array}$ & 4 & 0.6 \\
\hline \multirow[t]{3}{*}{ High } & Youth & 0 & 0 \\
\hline & Young adulthood & 137 & 23 \\
\hline & $\begin{array}{l}\text { Middle } \\
\text { adulthood }\end{array}$ & 1 & 0.2 \\
\hline
\end{tabular}

Most of the participants in the youth category have low level of psychological preparedness for disasters with $0.2 \%$ from the total population. 
Participants in the age between 15-24 years old were classified in the young adulthood category. Participant in this age category is mostly have average level of psychological preparedness for disaster $(67 \%)$. Whereas the low-level psychological preparedness for disaster in this age category were $10 \%$ and $23 \%$ of them were have a high level of psychological preparedness for disaster.

The distribution of level of psychological preparedness across different age are provided in table 4 .

\section{Discussions}

This study found that mainly population that participate in this study has average level of psychological preparedness for disaster. Beside of that, the descriptive statistical analysis shown that there are differences of psychological preparedness for disaster level between socioeconomic status and age group.

The data shows that low-income status participants largely have average level of psychological preparedness for disaster followed by the group with high level of psychological preparedness for disaster and the last was group with low level of psychological preparedness for disaster. This pattern is also applied for participants in middle-income and high-income group. Different pattern of psychological preparedness for disaster could be seen between people in high income group. In this group, the percentage of people with high level of psychological preparedness for disaster is the same as with the percentage of people that have low level of psychological preparedness for disaster. The data shows that majority of the population with low level of psychological preparedness for disaster were coming from low-income status.

Study on the relationship between natural disasters and poverty in Fiji found that there is intercorrelation between the two variables [18]. In this study, poverty increase the Fiji people vulnerability to disaster. the same conclusion also found in the study of socioeconomic vulnerability of Vietnamese toward flooding [19]. The study found that poor household are the most vulnerable group that will experience a severe impact of flood compare to their counterpart. This is also true in the context of Sri Lanka population [20]. The financial condition influences people's sensitivity toward disaster and its impact. It is also found on several disaster preparedness research that the number of available resources affect the disaster preparedness reciprocally $[21,22]$. Low socioeconomic people have the lowest level of psychological preparedness since they could only have a limited resources an access to disaster risk reduction effort (e.g., training, post disaster aid and other related support for survivor after disaster). Hence, lack of access to disaster related aid support is one of the reasons that made and people in the low-income group have low level of psychological preparedness for disaster compare to others group. Thus, economic vulnerability influences individual disaster preparedness capacity.

Data analysis also show that level of psychological preparedness for disaster also differ between age. Low level of psychological preparedness for disaster were found among youth and young adulthood age group.
While high level of psychological preparedness for disaster were found between young and middle adulthood. Study on the disaster preparedness has found that youngster have higher level of fear toward disaster compare to the others age group [23]. According to this study, young people have several sources of fear that related to disaster. first fear of their parent health condition. Secondly, afraid of their own health, and afraid of material losses as a result of disaster. Although there has been found that psychological preparedness for disaster of coastal communities is found difference between socioeconomic status and age. Nevertheless, future research should further investigate the role of fear toward psychological preparedness for disaster.

\section{Conclusions}

The result shows that the psychological preparedness for disaster of the participants was mostly in average level. Therefore, there is a need to improve the condition especially among people in youth and young adulthood category with age between 1-24 years old in order to mitigate and lower the risk of psychological impact of disaster.

Acknowledgement. We would like to thank you Indonesia Ministry of Education, Culture, Research and Technology which has fund this research as part of the Penelitian Dasar (PD) research grant scheme.

\section{References}

1. BNPB, (2021)

2. CNN Indonesia, CNN Indonesia (2021)

3. P. B. S. Putro, Social and Economic Impacts of the Sidoarjo Mud Flow: Community Resettlement After Disaster, Tohoku Unversity of Japan, 2012

4. M. Filipski, L. Jin, X. Zhang, and K. Z. Chen, European Economic Review 116, 107 (2019)

5. G. Wong-Parodi and I. Feygina, Weather, Climate, and Society 10, 747 (2018)

6. L. S. King, J. D. Osofsky, H. J. Osofsky, C. F. Weems, T. C. Hansel, and G. M. Fassnacht, Current Psychology 34, 524 (2015)

7. M. B. Jacobs and E. W. Harville, Child and Youth Care Forum 44, 511 (2015)

8. N. Makwana, Journal of Family Medicine and Primary Care 8, 1 (2019)

9. H. Zulch, Psychological Preparedness for Natural Hazards - Improving Disaster Preparedness Policy and Practice (Brisbane, 2019)

10. H. Zulch, J. Reser, and P. Creed, 1 (2012)

11. S. A. Morrissey and J. P. Reser, The Australian Journal of Emergency Management 18, 46 (2003)

12. J. Roudini, H. R. Khankeh, and E. Witruk, Health Psychology Open 4, 1 (2017)

13. H. Zulch, Psychological Preparedness for Natural Disasters - Improving Disaster Management Theory and Practice, 2015

14. J. L. Boylan, The Development and Validation of The Bushfire Psychological Preparedness Scale (BPPS), The University of Western Australia, 2016 
15. L. S. Palupi, IOP Conference Series: Earth and Environmental Science 649, (2021)

16. L. S. Palupi and M. Noor Rahman Himawan, in E3S Web of Conferences, edited by B. W. Sudarno and T. T. Putranto (E3S Web Conference, 2020), pp. 0-5

17. B. Stern, L. Hurni, S. Wiesmann, and Y. Ysakowski, (2011)

18. P. N. Lal, R. Singh, and P. Holland, Relationship Between Natural Disasters and Poverty: A Fiji Case Study (2009)

19. R. Brouwer, A. Admiraal, K. Dusseldorp, T. Bui, and T. H. Tran, 1 (2010)

20. M. M. G. T. De Silva and A. Kawasaki, Ecological Economics 152, 131 (2018)

21. D. P. Eisenman, D. Glik, R. Maranon, L. Gonzales, and S. Asch, Journal of Health Care for the Poor and Underserved 20, 330 (2009)

22. B. M. Reininger, M. H. Rahbar, M. Lee, Z. Chen, S A. Raja, J. Pope, and B. Adams, Social Science and Medicine 83, 50 (2013)

23. V. M. Cvetković, A. Öcal, and A. Ivanov, International Journal of Disaster Risk Reduction 35, (2019) 